\title{
Mean platelet volume to lymphocyte ratio as a novel marker in patients with breast cancer who underwent curative resection
}

\author{
Stosunek średniej objętości płytek krwi do liczby limfocytów jako nowy marker u chorych \\ na raka piersi po pierwotnym zabiegu operacyjnym
}

Ankara Dışkapı Ylılııım Beyazıt Training and Research Hospital, Ankara, Turkey

Correspondence: Hayriye Şahinli, Ankara Dışkapı Yıldırım Beyazıı Training and Research Hospital, Şehit Ömer Halisdemir Street, Altındağ, Ankara, Turkey, tel.: 05536934969, e-mail: dr.hayriye@hotmail.com, ORCID ID: http://orcid.org/0000-0002-1561-9346

\begin{abstract}
Background: Platelets play an essential role in cancer progression and metastasis. Mean platelet volume (MPV) is considered to be an effective marker for platelet activation. There is a positive correlation between lymphopenia and cancer prognosis. This study aimed to determine the prognostic significance of MPV/lymphocyte ratio (MPVLR) in breast cancer patients undergoing curative resection. Methods: Data of 139 breast cancer patients who underwent curative resection between January 2013 and December 2018 were analyzed retrospectively. The chi-square test evaluated the relationship between MPVLR and clinicopathological variables. MPVLR was obtained by dividing MPV by lymphocyte count. The Kaplan-Meier log-rank test assessed the correlation between MPVLR and disease-free survival (DFS). Results: The median follow-up was 41 (13-66) months. The best predicted optimal cut-off value for MPVLR by receiver operating characteristic (ROC) analysis was 4.34 (sensitivity 0.556 , specificity 0.727 ). Patients were categorized into two groups as high MPVLR ( $>4.34)$ and low MPVLR (<4.34). The DFS rate in the elevated MPVLR group was significantly lower than in the low MPVLR group $(p=0.038)$. Multivariate analysis was not performed because only MPVLR was found significant for DFS in univariate analysis. We found a significant correlation between MPVLR and platelet to lymphocyte ratio (PLR) and MPV level. Conclusion: DFS was significantly shorter in patients with elevated MPVLR level. We believe that MPVLR can be used as a new prognostic marker in breast cancer patients undergoing curative resection.
\end{abstract}

Keywords: breast cancer, mean platelet volume, mean platelet volume to lymphocyte ratio, platelets

Streszczenie Wstęp: Płytki krwi odgrywają istotną rolę w progresji raka i tworzeniu przerzutów. Średnią objętość płytek krwi (mean platelet volume, MPV) uznaje się za skuteczny marker aktywacji płytkowej. Istnieje dodatnia korelacja między limfopenią a rokowaniem u chorych na raka. Celem badania było określenie znaczenia prognostycznego stosunku średniej objętości płytek krwi do liczby limfocytów (MPV/lymphocyte ratio, MPVLR) u chorych z rakiem piersi poddanych pierwotnemu zabiegowi operacyjnemu. Metody: Analizą retrospektywną objęto dane 139 pacjentek z rakiem piersi poddanych pierwotnej operacji w okresie od stycznia 2013 do grudnia 2018 roku. W celu oceny związku między wartością wskaźnika MPVLR a zmiennymi kliniczno-patologicznymi wykorzystano test chi-kwadrat. Wartość wskaźnika MPVLR otrzymano, dzieląc wartość MPV przez liczbę limfocytów. W celu oceny korelacji między wartością MPVLR a czasem przeżycia wolnego od choroby zastosowano test log-rank z estymatorem Kaplana-Meiera. Wyniki: Mediana czasu obserwacji wyniosła 41 (13-66) miesięcy. Najlepszy przewidywany optymalny punkt odcięcia dla wskaźnika MPVLR na krzywej ROC (receiver operating characteristic) wynosił 4,34 (czułość 0,556, specyficzność 0,727). Pacjentki podzielono na dwie grupy: $\mathrm{z}$ wysoką $(>4,34)$ i niską wartością MPVLR $(<4,34)$. Czas przeżycia wolny od choroby był istotnie krótszy w grupie z podwyższonym wskaźnikiem MPVLR w porównaniu z grupą z niskim wskaźnikiem MPVLR $(p=0,038)$. Nie przeprowadzono analizy wielowymiarowej, gdyż w analizie jednowymiarowej jedynie wskaźnik MPVLR wykazywał istotność pod kątem czasu przeżycia wolnego od choroby. Autorzy stwierdzili istotną korelację między wskaźnikiem MPVLR a stosunkiem płytek krwi do limfocytów (platelet to lymphocyte ratio, PLR) i poziomem MPV. Wniosek: Czas przeżycia wolny od choroby był istotnie krótszy u chorych z wyższymi wartościami wskaźnika MPVLR. Zdaniem autorów wskaźnik MPVLR można stosować jako nowy prognostyczny marker u chorych na raka piersi leczonych operacyjnie.

Słowa kluczowe: rak piersi, średnia objętość płytek krwi, stosunek średniej objętości płytek krwi do liczby limfocytów, płytki krwi 


\section{INTRODUCTION}

$\mathrm{B}$ reast cancer is the most common cancer among women worldwide and is the leading cause of cancer-related death in women. The prognosis for breast cancer is still poor, despite improvements in adjuvant chemotherapy and hormonal therapy. The prognosis of patients depends on various factors such as patient-specific characteristics (performance, age, race, etc.), tumor biology (tumor diameter, nodal status, histological grade), and gene expression profiles ${ }^{(1)}$. However, these factors are insufficient to determine prognosis. Although adjuvant systemic treatment has been successful in reducing mortality, most patients cannot be treated appropriately or are overtreated. Affordable and reliable prognostic factors are critical in determining the risk of recurrence in these patients.

The immune system plays an essential role in preventing the development and progression of cancer ${ }^{(2)}$. Lymphocytes that make up 30\% of circulating white blood cells are effector cells of cellular immunity to tumor cells ${ }^{(3)}$. Studies have concluded that low lymphocyte count is associated with poor prognosis in many cancers ${ }^{(4)}$.

Platelets have been reported to play a positive role in tumor angiogenesis and metastatic dissemination. High platelet count is a poor prognostic factor in many cancer types ${ }^{(5-7)}$. Mean platelet volume (MPV) is the most commonly used method for measuring platelet diameter in clinical practice. MPV is also an indicator of platelet function and activation. It is also associated with various inflammatory conditions ${ }^{(8)}$. This parameter is a simple and inexpensive test that is routinely measured. It has practical and prognostic importance in some diseases. Elevated MPV levels have been determined in various cancers such as hepatocellular carcinoma, ovarian cancer, colon cancer, lung, and breast cancer ${ }^{(9-12)}$.

No studies have investigated the prognostic value of MPV/lymphocyte ratio (MPVLR) in patients with localized breast cancer. In this study, we aimed to investigate the prognostic value of the MPVLR in patients with curative resection of breast cancer.

\section{METHODS}

The study included 139 patients who underwent curative resection for breast cancer between January 2013 and December 2018. Data were obtained retrospectively from electronic records and patient files. Male patients, patients with metastasis at diagnosis, patients with carcinoma in situ, patients with bilateral breast cancer, a history of preoperative treatment, autoimmune diseases, dialysis patients and patients with heart failure were not included in the study. Adjuvant treatment was performed according to the NCCN (National Comprehensive Cancer Network) Guidelines. The clinicopathological features of the patients were recorded. Estrogen and progesterone receptor status were evaluated via immunohistochemistry (IHC). Receptor expression scores above 0 were accepted as positive. IHC and fluorescence in situ hybridization assessed human epidermal growth factor receptor 2 (HER2) status. IHC score of 3 or at least a 2.2 -fold stronger HER2 signal relative to the centromere enumeration probe for chromosome 17 (CEP-17) signal in the tumor cells were considered HER2 positive. MPVLR was obtained by dividing MPV by lymphocyte count.

This study was in accordance with the ethical standards of the World Medical Association's Declaration of Helsinki.

\section{Statistical analysis}

SPSS 20.0 (IBM Corporation, New York, NY) program was used for all statistical analyses. MPV, MPVLR, and MPVPR (MPV/platelet ratio) levels were determined before the initiation of any adjuvant treatment. Receiver operating characteristic (ROC) analysis was used to find the ratio reflecting the highest sensitivity and specificity. The median value was taken as the cut-off value for platelet to lymphocyte ratio (PLR). The chi-square test evaluated the correlation between MPVLR and clinicopathological characteristics. Disease-free survival (DFS) was calculated from the time of diagnosis until the relapse of the disease. Survival curves were estimated using the Kaplan-Meier method. Independent prognostic factors were identified via univariate analysis, using a long rank test to identify any independent variables associated with DFS. $p<0.05$ was considered statistically significant.

\section{RESULTS}

One hundred thirty-nine patients were analyzed in this study. The median age of the patients at the time of diagnosis was $54(22-88)$ years. The median follow-up was

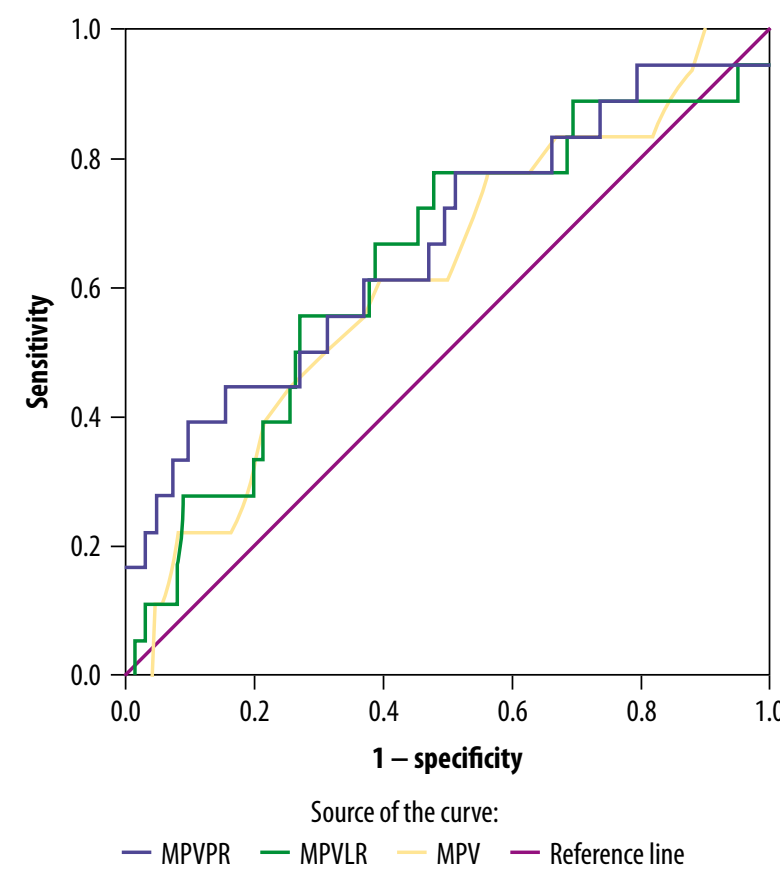

Fig. 1. ROC curve analysis of DFS for MPVLR, MPVPR and $M P V$ 


\begin{tabular}{|c|c|c|c|}
\hline \multirow[b]{2}{*}{ Characteristics } & \multicolumn{3}{|c|}{ MPVLR } \\
\hline & $<4.34$ & $>4.34$ & $p$ value \\
\hline $\begin{array}{l}\text { Age [years]: } \\
\cdot \leq 50 \\
\cdot>50\end{array}$ & $\begin{array}{l}40 \\
57\end{array}$ & $\begin{array}{l}17 \\
25\end{array}$ & 0.933 \\
\hline $\begin{array}{l}\text { Tumor size }[\mathrm{cm}]: \\
\cdot<2 \mathrm{~cm} \\
\cdot \geq 2 \mathrm{~cm}\end{array}$ & $\begin{array}{l}29 \\
68\end{array}$ & $\begin{array}{l}14 \\
28\end{array}$ & 0.687 \\
\hline $\begin{array}{l}\text { Estrogen receptor: } \\
\text { - negative } \\
\text { - positive }\end{array}$ & $\begin{array}{l}14 \\
83 \\
\end{array}$ & $\begin{array}{c}9 \\
33\end{array}$ & 0.308 \\
\hline $\begin{array}{l}\text { Progesterone receptor: } \\
\text { - negative } \\
\text { - positive }\end{array}$ & $\begin{array}{l}17 \\
80\end{array}$ & $\begin{array}{l}13 \\
29\end{array}$ & 0.077 \\
\hline $\begin{array}{l}\text { HER2: } \\
\text { - negative } \\
\text { - positive } \\
\end{array}$ & $\begin{array}{l}62 \\
35\end{array}$ & $\begin{array}{l}32 \\
10\end{array}$ & 0.156 \\
\hline $\begin{array}{l}\text { Lymph node involvement: } \\
\text { - negative } \\
\text { - positive } \\
\end{array}$ & $\begin{array}{r}55 \\
42 \\
\end{array}$ & $\begin{array}{r}20 \\
22 \\
\end{array}$ & 0.324 \\
\hline $\begin{array}{l}\text { Grade: } \\
\cdot 1,2 \\
\cdot 3 \\
\end{array}$ & $\begin{array}{l}67 \\
30 \\
\end{array}$ & $\begin{array}{l}27 \\
15 \\
\end{array}$ & 0.580 \\
\hline $\begin{array}{l}\text { MPV [fL]: } \\
\cdot<8.75 \\
\cdot>8.75 \\
\end{array}$ & $\begin{array}{l}64 \\
33 \\
\end{array}$ & $\begin{array}{l}20 \\
22\end{array}$ & 0.042 \\
\hline \begin{tabular}{|l|} 
MPVPR: \\
$\cdot<3.18$ \\
$\cdot>3.18$
\end{tabular} & $\begin{array}{l}68 \\
29 \\
\end{array}$ & $\begin{array}{l}23 \\
19\end{array}$ & 0.081 \\
\hline $\begin{array}{l}\text { PLR: } \\
\cdot<126 \\
\cdot>126\end{array}$ & $\begin{array}{l}65 \\
32\end{array}$ & $\begin{array}{c}4 \\
38\end{array}$ & $<0.001$ \\
\hline
\end{tabular}

Tab. 1. Clinicopathological characteristics of patients stratified by MPVLR

41 (13-66) months. Recurrence occurred in 18 (12.9\%) patients during follow-up. The best cut-off values for MPV, MPVPR, and MPVLR were determined by ROC analysis and categorized into two groups (Fig. 1). The best cut-off values for MPV, MPVPR and MPVLR determined by ROC analysis were 8.75 (sensitivity 0.556 , specificity 0.628 ), 3.18 (sensitivity 0.556 , specificity 0.686 ), 4.34 (sensitivity 0.556 , specificity 0.727 ), respectively (Fig. 1). The median value was taken as the cut-off value for PLR ( $<126$ vs. $\geq 126)$.

Patients were categorized into two groups as high MPVLR $(>4.34)$ and low MPVLR $(<4.34)$, according to MPVLR. Of the 139 patients, 97 were in the low MPVLR group, and 42 were in the high MPVLR group. When the relationship between MPVLR and clinicopathological characteristics was assessed, a significant correlation was found for MPV $(p=0.042)$ and PLR $(p<0.001)$. There was no correlation between other clinicopathological characteristics (Tab. 1). Univariate analysis revealed significant impact only for MPVLR on DFS (Tab. 2). Median DFS was 60 months in high-MPVLR patients, whereas the median DFS was not detected in patients in the low-MPVLR group (Fig. 2). Progression-free survival (PFS) in the third year was $65.8 \%$ in patients with elevated MPVLR and $96.3 \%$ in patients group was significantly lower than in the low MPVLR group $(p=0.038)$ (Fig. 2).

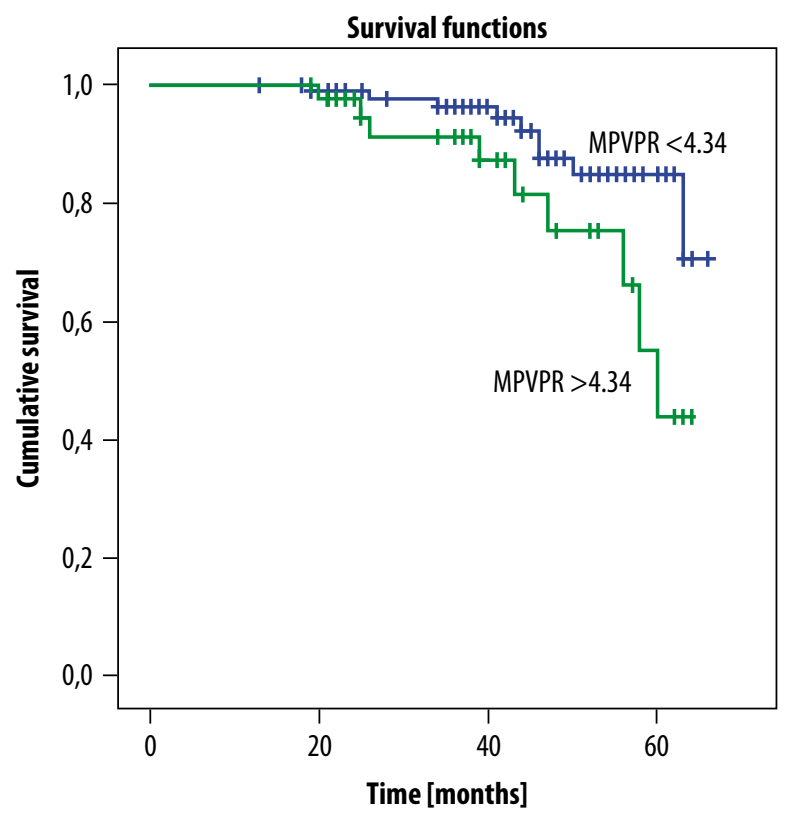

Fig. 2. Kaplan-Meier analysis of DFS stratified by MPVLR in breast cancer patients 


\begin{tabular}{|c|c|c|}
\hline Characteristics & Number of patients $(n)$ & $p$ value \\
\hline $\begin{array}{l}\text { Age [years]: } \\
\cdot \leq 50 \\
\cdot>50\end{array}$ & $\begin{array}{l}57 \\
82\end{array}$ & 0.87 \\
\hline $\begin{array}{l}\text { Tumor size: } \\
\cdot<2 \mathrm{~cm} \\
\cdot \geq 2 \mathrm{~cm}\end{array}$ & $\begin{array}{l}43 \\
96\end{array}$ & 0.198 \\
\hline $\begin{array}{l}\text { Lymph node involvement: } \\
\text { - yes } \\
\text { - no } \\
\end{array}$ & $\begin{array}{l}64 \\
75 \\
\end{array}$ & 0.154 \\
\hline $\begin{array}{l}\text { Estrogen receptor: } \\
\text { - positive } \\
\text { - negative }\end{array}$ & $\begin{array}{l}116 \\
23\end{array}$ & 0.841 \\
\hline $\begin{array}{l}\text { Progesterone receptor: } \\
\text { - positive } \\
\text { - negative }\end{array}$ & $\begin{array}{c}109 \\
30\end{array}$ & 0.999 \\
\hline $\begin{array}{l}\text { HER2: } \\
\text { - positive } \\
\text { - negative }\end{array}$ & $\begin{array}{r}45 \\
94 \\
\end{array}$ & 0.443 \\
\hline $\begin{array}{l}\text { PLR: } \\
\cdot<126 \\
\cdot \geq 126\end{array}$ & $\begin{array}{l}69 \\
70\end{array}$ & 0.817 \\
\hline $\begin{array}{l}\text { MPV [fL]: } \\
\cdot<8.75 \\
\cdot>8.75\end{array}$ & $\begin{array}{l}84 \\
55 \\
\end{array}$ & 0.120 \\
\hline $\begin{array}{l}\text { MPVPR: } \\
\cdot \leq 3.18 \\
\cdot>3.18 \\
\end{array}$ & $\begin{array}{l}91 \\
48 \\
\end{array}$ & 0.095 \\
\hline $\begin{array}{l}\text { MPVLR } \\
\cdot \leq 4.34 \\
\cdot>4.34\end{array}$ & $\begin{array}{l}97 \\
42\end{array}$ & 0.038 \\
\hline
\end{tabular}

Tab. 2. Clinicopathological characteristics: univariate analyses of disease-free survival in breast cancer

\section{DISCUSSION}

This is the first study showing the prognostic significance of MPVLR in patients with breast cancer who underwent curative resection. DFS was shorter in patients with high MPVLR (MPVLR $>4.34)$ than in patients with low MPVLR $(<4.34)$. Recent studies have shown that the host inflammatory response plays a role in tumor development and progression. The inflammatory response has a crucial role in tumor microenvironment and tumor formation ${ }^{(13)}$. Serum biomarkers of inflammation are readily obtained by peripheral blood sampling. Complete blood count (CBC) is routinely performed in cancer patients. The prognostic significance of some biomarkers such as platelet count, MPV, PLR, and NLR (neutrophil to lymphocyte ratio) has been determined in many cancers ${ }^{(14,15)}$. Lymphocytes are the main components of the immune system. Tumor-infiltrating lymphocytes are the main components of the antitumor immune microenvironment ${ }^{(16)}$. Studies have shown that lymphocytes can recognize and kill tumor cells and release various cytokines to activate the host immune system. Therefore, low lymphocyte count is an indicator of poor prognosis in cancer patients ${ }^{(4)}$.

Studies have concluded that platelets play a role in cancer metastasis and angiogenesis. Thrombocytosis is an indicator of poor prognosis in many cancer types such as stomach cancer, pancreas cancer, colorectal cancer, ovarian cancer and endometrial cancer ${ }^{(17-19)}$. MPV is an index showing a mean platelet diameter and platelet activity. Platelet diameter shows platelet activity better than platelet number ${ }^{(20)}$. MPV level is correlated with poor prognosis in various malignancies, such as breast cancer, endometrial cancer and advanced gastric cancer $^{(21,22)}$. PLR is known to have prognostic importance in many cancers ${ }^{(23)}$. PLR has also been shown to be a poor prognostic factor in breast cancer ${ }^{(24)}$. The presence of MPV, which is a better indicator of platelet activity rather than platelet in PLR, will make it a stronger prognostic marker.

There was no correlation between DFS and commonly recognized prognostic factors such as tumor size, receptor status or lymph node involvement in the study group ${ }^{(1)}$. We believe that the main reason for this is the small number of patients and the short follow-up period.

Our study has some limitations, such as a short follow-up period, a single-center and retrospective study.

In conclusion, this study is the first to show that elevated MPVLR may be important prognostic marker for diseasefree survival in breast cancer patients undergoing curative resection. MPVLR is easily accessible and easily calculated from routine hematological parameters. However, further studies are needed for it to be used as a prognostic marker in practice. 


\section{Conflict of interest}

The authors do not report any financial or personal connections with other persons or organizations, which might negatively affect the contents of this publication and/or claim authorship rights to this publication.

\section{References}

1. Faria SS, Fernandes PC Jr, Silva MJ et al.: The neutrophil-to-lymphocyte ratio: a narrative review. Ecancermedicalscience 2016; 10: 702.

2. Diakos CI, Charles KA, McMillan DC et al.: Cancer-related inflammation and treatment effectiveness. Lancet Oncol 2014; 15: e493-e503.

3. Mellman I, Coukos G, Dranoff G: Cancer immunotherapy comes of age. Nature 2011; 480: 480-489.

4. Zhou XL, Zhu WG, Zhu ZJ et al.: Lymphopenia in esophageal squamous cell carcinoma: relationship to malnutrition, various disease parameters, and response to concurrent chemoradiotherapy. Oncologist 2019; 24: e677-e686.

5. Chen N, Li W, Huang K et al.: Increased platelet-lymphocyte ratio closely relates to inferior clinical features and worse longterm survival in both resected and metastatic colorectal cancer: an updated systematic review and meta-analysis of 24 studies. Oncotarget 2017; 8: 32356-32369.

6. Gu X, Gao XS, Cui M et al.: Clinicopathological and prognostic significance of platelet to lymphocyte ratio in patients with gastric cancer. Oncotarget 2016; 7: 49878-49887.

7. Olsson AK, Cedervall J: The pro-inflammatory role of platelets in cancer. Platelets 2018; 29: 569-573.

8. Gasparyan AY, Ayvazyan L, Mikhailidis DP et al.: Mean platelet volume: a link between thrombosis and inflammation? Curr Pharm Des 2011; 17: 47-58.

9. Cho SY, Yang JJ, You E et al.: Mean platelet volume/platelet count ratio in hepatocellular carcinoma. Platelets 2013; 24: 375-377.

10. Kemal Y, Demirağ G, Ekiz K et al.: Mean platelet volume could be a useful biomarker for monitoring epithelial ovarian cancer. J Obstet Gynaecol 2014; 34: 515-518.

11. Mutlu H, Berk V, Karaca $\mathrm{H}$ et al.: Treatment regimen with bevacizumab decreases mean platelet volume in patients with metastatic colon cancer. Clin Appl Thromb Hemost 2012; 18: 546-548.
12. Aksoy S, Kilickap S, Hayran M et al.: Platelet size has diagnostic predictive value for bone marrow metastasis in patients with solid tumors. Int J Lab Hematol 2008; 30: 214-219.

13. Balkwill F, Mantovani A: Inflammation and cancer: back to Virchow? Lancet 2001; 357: 539-545.

14. Zhang F, Chen Z, Wang P et al.: Combination of platelet count and mean platelet volume (COP-MPV) predicts postoperative prognosis in both resectable early and advanced stage esophageal squamous cell cancer patients. Tumour Biol 2016; 37: 9323-9331.

15. Arigami T, Okumura $\mathrm{H}$, Matsumoto $\mathrm{M}$ et al.: Analysis of the fibrinogen and neutrophil-lymphocyte ratio in esophageal squamous cell carcinoma: a promising blood marker of tumor progression and prognosis. Medicine (Baltimore) 2015; 94: e1702.

16. Dunn GP, Old LJ, Schreiber RD: The immunobiology of cancer immunosurveillance and immunoediting. Immunity 2004; 21 : 137-148.

17. Suzuki K, Aiura K, Kitagou M et al.: Platelets counts closely correlate with the disease-free survival interval of pancreatic cancer patients. Hepatogastroenterology 2004; 51: 847-853.

18. Qiu J, Yu Y, Fu Y et al.: Preoperative plasma fibrinogen, platelet count and prognosis in epithelial ovarian cancer. J Obstet Gynaecol Res 2012; 38: 651-657.

19. Li MM, Yue CX, Fu S et al.: Platelet volume is reduced in metastasing breast cancer: blood profiles reveal significant shifts. Cancer Manag Res 2019; 11: 9067-9072.

20. Kurtul A, Acikgoz SK: Usefulness of mean platelet volume-tolymphocyte ratio for predicting angiographic no-reflow and short-term prognosis after primary percutaneous coronary intervention in patients with ST-segment elevation myocardial infarction. Am J Cardiol 2017; 120: 534-541.

21. Kurtoglu E, Kokcu A, Celik H et al.: Platelet indices may be useful in discrimination of benign and malign endometrial lesions, and early and advanced stage endometrial cancer. Asian Pac J Cancer Prev 2015; 16: 5397-5400.

22. Matowicka-Karna J, Kamocki Z, Polińska B et al.: Platelets and inflammatory markers in patients with gastric cancer. Clin Dev Immunol 2013; 2013: 401623.

23. Hirahara T, Arigami T, Yanagita $S$ et al.: Combined neutrophillymphocyte ratio and platelet-lymphocyte ratio predicts chemotherapy response and prognosis in patients with advanced gastric cancer. BMC Cancer 2019; 19: 672.

24. Zhu Y, Si W, Sun Q et al.: Platelet-lymphocyte ratio acts as an indicator of poor prognosis in patients with breast cancer. Oncotarget 2017; 8: 1023-1030. 